Archive for

Organic Chemistry

Arkivoc 2018, part iii, 165-173

\title{
An efficient and direct synthesis of substituted 2-phenylquinoline- 4-carboxamides from 3-substituted-3-hydroxyindolin-2-ones
}

\author{
Keshri Nath Tiwari, * Rinku Choubey, Saumya Shukla, and Parul Gautam \\ Department of Medicinal Chemistry, National Institute of Pharmaceutical Education \\ and Research (NIPER), ITI Compound, Raebareli 229 010, India \\ Email: keshri.tiwari@niperraebareli.edu.in
}

Received 06-26-2017

Accepted 11-30-2017

Published on line $02-18-2018$

\section{Abstract}

A simple and direct synthesis of substituted 2-phenylquinoline-4-carboxamides from 3-substituted-3hydroxyindolines in presence of ammonium acetate is described. The developed protocol also allows synthesis of the carboxamide moeity directly from isatin and acetophenone in one pot under optimized conditions. The protocol has the merits of simple reaction conditions, easy work up process and good yields of products.
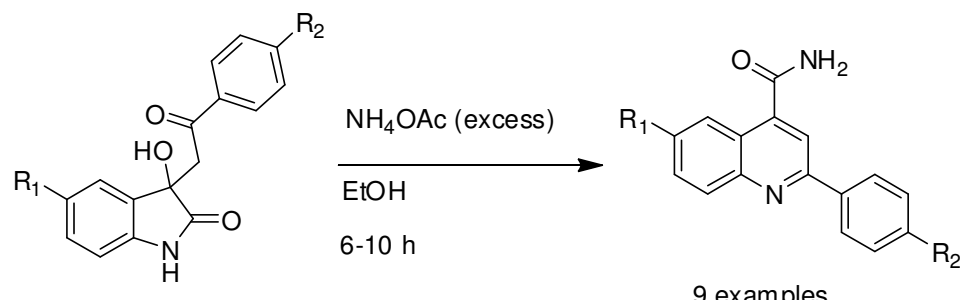

9 examples

$65-74 \%$ yield

Keywords: 2-Phenylquinoline-4-carboxamide, ammonium acetate, 3-hydroxyindolin-2-ones 


\section{Introduction}

Quinoline derivatives are an important class of structural motif that is posed with diverse chemotherapeutic activities like antimicrobial, ${ }^{1}$ antiviral, ${ }^{2}$ antimalarial ${ }^{3}$ and anti-inflammatory. ${ }^{4}$ Since the discovery of cinchophen (I) (2-phenylquinoline-4-carboxylic acid) as an analgesic drug, this pharmacophore has been extensively explored for the synthesis of antibacterial agents. ${ }^{5-7}$ The structure activity relationship of these molecules have also revealed that the presence of aryl group at 2-position of quinoline ring is crucial for their bioactivity. ${ }^{8}$

In particular, the 2-phenylquinoline-4-carboxamide (II) moiety have been identified and developed as potent and selective non-peptide competitive antagonists for human neurokinin-3 receptor. ${ }^{9}$ The 2phenylquinolines bearing a (S)- $\mathrm{N}$-(1-phenylpropyl)carboxamide functionality at the 4 position (III) represent a class of highly potent antagonists of the NK-3 receptor. They have also been extensively studied for their application as a ligand suitable for radiolabeling. In fact, Many of these radioactive labelled molecules have been evaluated as radiotracer of NK-3 receptor for PET imaging studies. ${ }^{10}$ Quinoline-4-carboxamide analogues (IV) have also been studied as a potential type II binding compounds with cytochrome CYP2C9 protein which is mainly responsible for drug metabolism. ${ }^{11,12}$
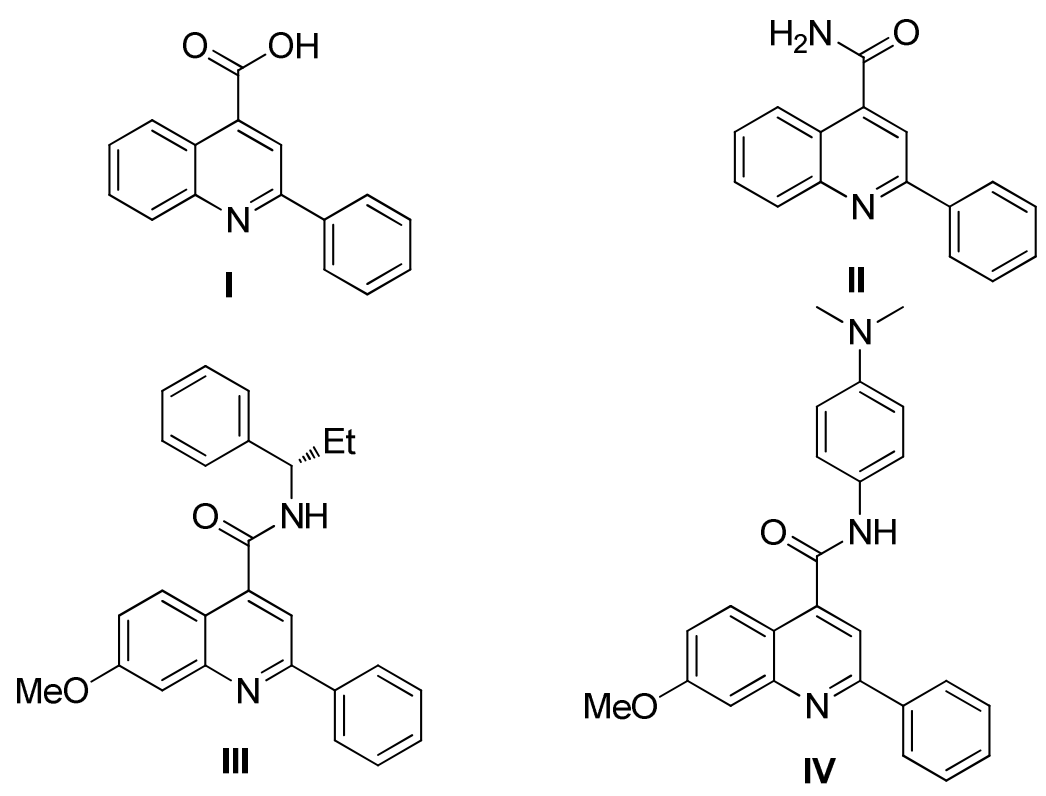

Figure 1. Some biologically active 2-phenylquinoline-4-carboxamides.

Despite there being plenty of applications in medicinal chemistry, the direct synthesis of 2phenylquinoline-4-carboxamide has limited reported methods. ${ }^{13-15}$ They are usually obtained from 2phenylquinoline-4-carboxylic acid (Cinchophen) which is usually synthesized by Pfitzinger or Doebner reactions. ${ }^{16}$ While the Pfitzinger reaction involves an isatin and an aryl methyl ketone in the presence of potassium hydroxide which allows the synthesis of 2-phenylquinoline-4-carboxylic acid whereas the Doebner reaction gives a similar kind of product by a three-component reaction between pyruvic acid, benzaldehyde, and an aniline. There are limited literature reports for the synthesis of 2-phenylquinoline-4-carboxamide. ${ }^{17-19}$ An elegant method for one-step synthesis of 2-phenylquinoline-4-carboxylates and carboxamides from arylimines and acrylates or acrylamides were reported under microwave conditions catalyzed by indium chloride. $^{20}$ 
As a part of our research plan aimed at developing new synthetic methods for the creation of biologically relevant heterocyclic compounds in aqueous media, recently we have reported the synthesis of 3-substituted3-hydroxyindolin-2-ones by aldol reactions between isatin and acetophenone catalysed by DABCO (Scheme 1). ${ }^{21}$ The copper catalysed ${ }^{22}$ and $\mathrm{Cs}_{2} \mathrm{CO}_{3}$ mediated ${ }^{23}$ efficient methods for the synthesis of 3-hydoxyindolin-2ones have also been documented recently. Now, we wish to report an efficient method for the direct synthesis of 2-phenylquinoline-4-carboxamide derivatives by ring-opening and cyclization of 3-substituted-3hydroxyindolin-2-ones.<smiles>[R7]c1ccc2c(c1)C(=O)C(=O)N2</smiles>
$1 \mathrm{a}\left(\mathrm{R}_{\mathbf{1}}=\mathrm{H}\right)$<smiles>[R2]c1ccc(C(C)=O)cc1</smiles>

$2 \mathrm{a}\left(\mathrm{R}_{\mathbf{2}}=\mathrm{H}\right)$
$\mathrm{DABCO}$ (cat.) $\mathrm{H}_{2} \mathrm{O}, 80^{\circ} \mathrm{C}$

$1-3 h$

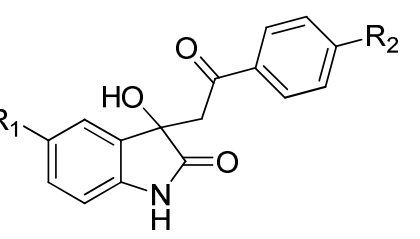

$3 a\left(R_{1}, R_{2}=H\right)$

Scheme 1. Synthesis of 3-susbstituted-3-hydroxy-2-oxindole (3a).

\section{Results and discussion}

Initially, we began the synthesis by heating of the 3-substituted-3-hydroxyindolin-2-one (3a) in the presence of excess of ammonium acetate in $\mathrm{EtOH}$ at $80{ }^{\circ} \mathrm{C}$ (Scheme 2). After TLC indicated the complete consumption of 3a, the solvent was evaporated, leaving a brown-colored solid. This brown solid was dissolved in a large volume of dichloromethane with the addition of few drops of methanol. The solution was left for overnight and the product $4 \mathrm{a}$ crystallized out as a white solid. The structure of $\mathbf{4 a}$ was confirmed by ${ }^{1} \mathrm{H},{ }^{13} \mathrm{C} N M R, I R$ and mass spectral analysis. Although the TLC indicated the complete conversion of $\mathbf{3 a}$ into $\mathbf{4 a}$, the yield of the product was found low. It was realized by TLC that a significant amount of the product (4a) was present in the mother liquor. We therefore purified the reaction mixture by silica gel column chromatography and the product was isolated with $72 \%$ yield.
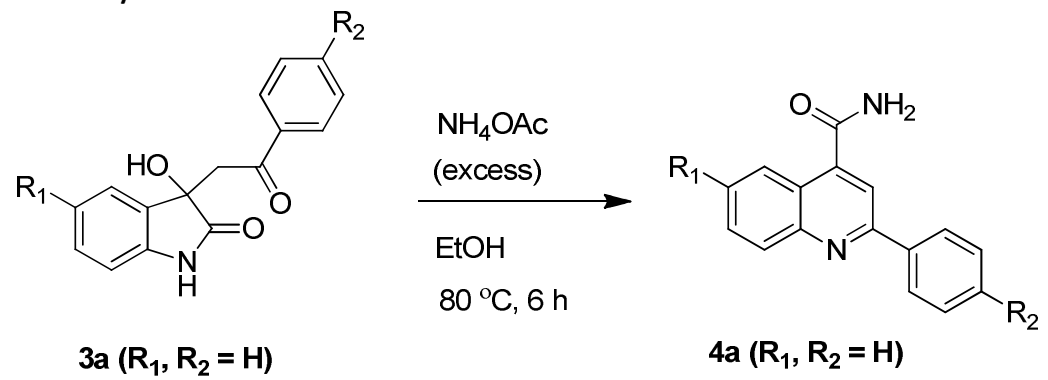

Scheme 2. Synthesis of 2-phenylquinoline-4-carboxamide (4a).

We also investigated the efficiency of the reaction in different solvents for optimal conditions. For this, the reaction was performed with $\mathbf{3 a}$ on a $300 \mathrm{mg}$ scale in various solvents (Table 1). Although the expected product was obtained in most of the solvents, $\mathrm{EtOH}$ was found a better solvent with respect to reaction time and yield.

During the synthesis of $\mathbf{3 a}$, it was observed that the product separated out as solid in water and it was almost pure. We had also found that the reaction can also be performed in EtOH. ${ }^{21}$ Keeping this in view, we 
planned to make this two step reaction in one pot. Therefore, isatin (1a) and acetophenone (2a) were heated in EtOH using DABCO as a catalyst for 2 hours. After the TLC indicated the consumption of $1 \mathrm{a}$ and $2 \mathrm{a}, \mathrm{NH}_{4} \mathrm{OAC}$ was added to the reaction mixture portion wise and the mixture heated for a further 4 hours. To our satisfaction, the compound 4 a obtained in $60 \%$ yield (Scheme 3 ). It was interesting to note that the portion wise addition of ammonium acetate ( 4 to 5 eq.) at regular intervals of 2 hours was found more efficient that one-time addition.

Table 1. Optimization of solvents for the synthesis of 4 a from $3 a$

\begin{tabular}{ccccc}
\hline Entry & Solvent & Base & Time $(\mathrm{h})$ & ${\text { Yield }(\%)^{a}}^{a}$ \\
\hline 1 & EtOH & DABCO & $6 \mathrm{~h}$ & 72 \\
2 & $\mathrm{CH}_{3} \mathrm{CN}$ & DABCO & $10 \mathrm{~h}$ & 40 \\
3 & $\mathrm{DMF}$ & DABCO & $10 \mathrm{~h}$ & 45 \\
4 & $\mathrm{CHCl}_{3}$ & DABCO & $12 \mathrm{~h}$ & 30 \\
5 & $\mathrm{THF}$ & DABCO & $12 \mathrm{~h}$ & 25 \\
6 & $\mathrm{H}_{2} \mathrm{O}$ & DABCO & $10 \mathrm{~h}$ & No product \\
\hline
\end{tabular}

${ }^{a}$ isolated yield

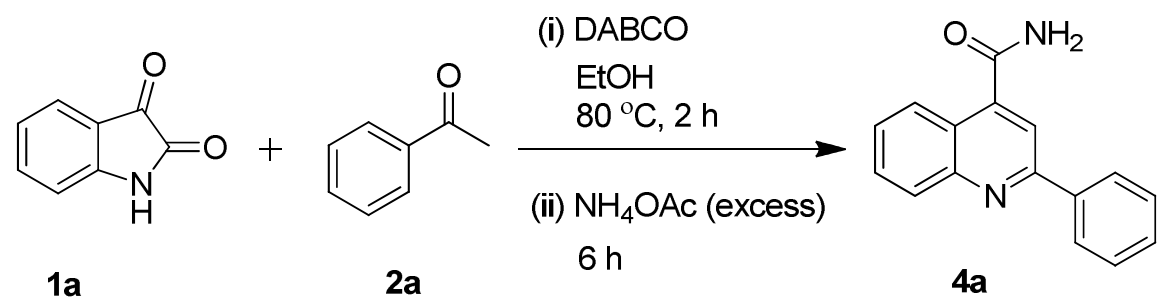

Scheme 3. One pot synthesis of 2-phenylquinoline-4-carboxamide (4a).

The scope of the substrate for this transformation was studied using substituted isatins and acetophenones (Scheme 4). It was observed that the second step of the reaction was generally prolonged by about 3-4 times in comparison to the duration of first step. The reaction time in the table indicates the total reaction time over both the steps (Table 2 ).

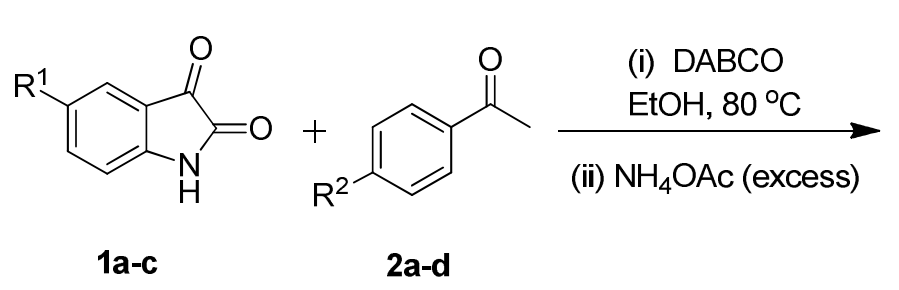<smiles>[R]c1ccc(-c2cc(C(N)=O)c3cc([R])ccc3n2)cc1</smiles>

Scheme 4. Synthesis of 4-arylquinoline-4-carboxamides 4a-i.

As reflected in the Table 2, the electronic effect of substituents was also observed during the reaction. The reaction time for unsubstituted isatin was found relatively less ( $6 \mathrm{~h}$ ) in comparison to 5-chloro/bromo substitution $(10 \mathrm{~h})$ and the yield was found less for 5-bromo isatin. It indicates that chloro/bromo substitution at 5 position of isatin retards the reaction. For acetophenone, the yield was found maximum (74\%) with 4methyl substitution and minimum (68\%) for 4-bromo substitution. This indicates that electron donation group 
at 4-position of acetophenone is found more reactive substrate for this synthetic transformation (Table 2).

Table 2. Scope of substrate with reaction time and yield of product (4a-i)

\begin{tabular}{ccccc}
\hline Entry & Isatin $\left(\mathrm{R}^{1}\right)$ & Acetophenone $\left(\mathrm{R}^{2}\right)$ & Time $(\mathrm{h})$ & $\begin{array}{c}\text { Product (4a-i) } \\
(\text { Yield \%) }\end{array}$ \\
\hline 1 & $\mathrm{H}$ & $\mathrm{H}$ & 6 & $\mathbf{4 a}(72)$ \\
2 & $\mathrm{H}$ & $\mathrm{CH}_{3}$ & 12 & $\mathbf{4 b}(74)$ \\
3 & $\mathrm{H}$ & $\mathrm{OCH}_{3}$ & 12 & $\mathbf{4 c}(70)$ \\
4 & $\mathrm{Cl}$ & $\mathrm{H}$ & 10 & $\mathbf{4 d}(65)$ \\
5 & $\mathrm{Cl}$ & $\mathrm{CH}_{3}$ & 10 & $\mathbf{4 e}(74)$ \\
6 & $\mathrm{Cl}$ & $\mathrm{OCH}_{3}$ & 8 & $\mathbf{4 f}(75)$ \\
7 & $\mathrm{Cl}$ & $\mathrm{Br}_{8}$ & 8 & $\mathbf{4 g}(68)$ \\
8 & $\mathrm{Br}$ & $\mathrm{H}$ & 10 & $\mathbf{4 h}(68)$ \\
9 & $\mathrm{Br}$ & $\mathrm{OCH}_{3}$ & 10 & $\mathbf{4 i}(70)$ \\
\hline
\end{tabular}

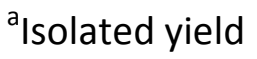

The characterization of all the compounds was done by ${ }^{1} \mathrm{H},{ }^{13} \mathrm{C}$ NMR and IR spectra as well as HRMS analysis. The mass spectra of all synthesized compounds showed a characteristic $[\mathrm{M}+\mathrm{H}]^{+}$peak. The IR spectra of 4 a showed characteristic two peaks of amide carbonyl $\left(\mathrm{CONH}_{2}\right)$ at $1660 \mathrm{~cm}^{-1}$ and $1588 \mathrm{~cm}^{-1}$ and two peaks for $\mathrm{NH}_{2}$ were observed at $3373 \mathrm{~cm}^{-1}$ and $3150 \mathrm{~cm}^{-1}$. A similar pattern was observed for all the other compounds. The ${ }^{1} \mathrm{H}$ NMR spectra of compound 4 a showed the disappearance of $-\mathrm{CH}_{2}$ and $\mathrm{OH}$ protons which were observed in 3a. The chemical shifts of all the aromatic protons of quinoline and phenyl ring were observed in between $\delta 7.2 \mathrm{ppm}$ to $8.5 \mathrm{ppm}$. The $\mathrm{NH}_{2}$ protons of amide were observed at approx. $\delta 8.0 \mathrm{ppm}$. The ${ }^{13} \mathrm{C}$ NMR showed a characteristic peak at $\delta 168 \mathrm{ppm}$ in $4 \mathrm{a}$ amide carbonyl $\left(\mathrm{CONH}_{2}\right)$. The melting point of compound $4 \mathrm{a}$ was found in good agreement with the literature report. ${ }^{24}$

In this way, a series of 9 molecules was synthesized and fully characterized by various spectral analysis bearing substitution on both isatin and acetophenone. The synthesized molecules with their reaction times and yields are given in Scheme 4 and Table 2.

A plausible route to the formation of $\mathbf{4 a}$ from the intermediate $3 \mathbf{3 a}$ can be explained as the ammonium acetate decomposes to give ammonia which attacks the carbonyl to give imine (5) which undergoes tautomerization to provide an enamine (6). The amino group then attacks the carbonyl of the indolinone to give an intermediate pyrrolenone with aniline residue (7). Further cyclization of the aniline with imine provide benzodiazepinone (8) which after ring-opening and release the amide group provides 4hydroxydihydroquinoline (9) and further elimination of water provides the product $4 \mathrm{a}$. This sequence is shown in Scheme 5. The DABCO is used as a base for aldol reaction between isatin (1a) and acetophenone (2a) in the first step for the synthesis of 3-substituted-3-hydroxyindolin-2-one (3a). 
<smiles>CC1CC1CC1(O)C(=O)Nc2ccccc21</smiles><smiles>C=CC1(O)C(=O)Nc2ccccc21</smiles><smiles>Nc1ccccc1C1(O)C=C(c2ccccc2)NC1=O</smiles><smiles>CCCC1(c2ccccc2N)CC(O)(c2ccccc2)C(=O)N1</smiles><smiles>NC(=O)c1cc(-c2ccccc2)nc2ccccc12</smiles>

Scheme 5. A plausible mechanism for formation of 2-phenylquinoline-4-carboxamide (4a).

\section{Conclusion}

In summary, we have developed an efficient and direct method for the synthesis of substituted 2phenylquinoline-4-carboxamide by ring opening and cyclization of 3-hydroxyindolines. This method is applicable to a wide substrate scope for both the isatin and acetophenone and provides a series of quinoline4-carboxamides which represent a pharmaceutically important scaffold. The reaction conditions and work up procedure is very simple with good yield of products. Further exploration of this methodology is currently under way in our laboratory and findings will be reported with due course.

\section{Experimental section}

General. Commercially available isatins, acetophenones and ammonium acetate from Spectrochem were used. Progress of reactions was monitored by thin layer chromatography (TLC). NMR spectra were recorded in DMSO $d_{6}$ at $400 \mathrm{MHz}$ for ${ }^{1} \mathrm{H}$ and $100 \mathrm{MHz}$ for ${ }^{13} \mathrm{C}$ on Bruker Avance DPX-400 MHz. Chemical shifts were

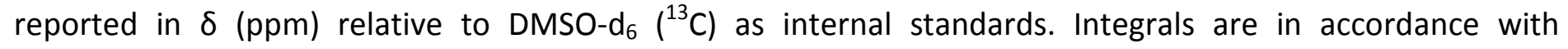
assignments, coupling constants are given in $\mathrm{Hz}$. The HRMS was recorded on a JOEL-AccuTOF JMS-T100LC Mass spectrometer having a DART source. The IR spectra were recorded on Spectrum RX-1 FTIR, Perkin Elmer. Yields refer to quantities obtained after chromatography. Melting points of compounds were recorded on Labindia make melting point apparatus. 


\section{Synthesis of 2-phenylquinoline-4-carboxamide (4a)}

A solution of $0.3 \mathrm{gm}(1.12 \mathrm{mmol})$ of $3 \mathrm{a}$ and $0.432 \mathrm{gm}$ of ammonium acetate $(5.6 \mathrm{mmol})$ was heated to $80{ }^{\circ} \mathrm{C}$ in EtOH for 6 hours. The ammonium acetate was added in portion wise at regular interval. After the TLC indicated the complete consumption of $\mathbf{3 a}$, the solvent was evaporated on rotatory evaporator to provide dark brown solid which was purified by silica gel column chromatography using hexane:EA (7:3) as an eluent to provide 4a as white colour solid. All the experiments for substituted compounds were performed in similar manner. The reaction times and yields of all the synthesized compounds are mentioned in the Results and Discussion section of the paper.

2-phenylquinoline-4-carboxamide (4a). White solid; 72\%, $195 \mathrm{mg}, \mathrm{mp} 190-191{ }^{\circ} \mathrm{C}$; IR ( $\left.\mathrm{KBr}\right): \mathrm{V}_{\max } 3373,3150$, 1669, $1588 \mathrm{~cm}^{-1}$; ${ }^{1} \mathrm{H}$ NMR (400 MHz, DMSO-d $)$ ): $\delta 8.31$ (dd, J $\left.8 \mathrm{~Hz}, 4 \mathrm{~Hz}, 2 \mathrm{H}, \mathrm{Ar}-\mathrm{H}\right), 8.27(\mathrm{~d}, J 8 \mathrm{~Hz}, 1 \mathrm{H}, \mathrm{Ar}-\mathrm{H})$, $8.16(\mathrm{~s}, 1 \mathrm{H}), 8.13(\mathrm{~d}, J 8 \mathrm{~Hz}, 1 \mathrm{H}, \mathrm{Ar}-\mathrm{H}) 7.93$ (bs 1H, NH) $7.82(\mathrm{t}, J 8 \mathrm{~Hz}, 1 \mathrm{H}) 7.65$ (t, J $8 \mathrm{~Hz}, 1 \mathrm{H}, \mathrm{Ar}-\mathrm{H}) 7.60-7.53$ (m, $3 \mathrm{H}, \mathrm{Ar}-\mathrm{H}) ;{ }^{13} \mathrm{C}$ NMR $\left(100 \mathrm{MHz}\right.$, DMSO- $\left.d_{6}\right): \delta$ 168.6, 155.7, 147.9, 143.0, 138.2, 130.0, 129.8, 129.4, 128.8, 127.2, 127.0, 125.4, 123.2, 116.5; HRMS (ESI) $\mathrm{m} / \mathrm{z}$ for $\mathrm{C}_{16} \mathrm{H}_{13} \mathrm{~N}_{2} \mathrm{O}[\mathrm{M}+\mathrm{H}]^{+}$, calcd., 249.1027, found, 249.1053

2-(p-tolyl)quinoline-4-carboxamide (4b). Light yellow solid; 74\%, $206 \mathrm{mg} ; \mathrm{Mp} 203-205{ }^{\circ} \mathrm{C} ; \mathrm{IR}(\mathrm{KBr}): \mathrm{V}_{\max } 3355$, $3152,1669,1596 \mathrm{~cm}^{-1} ;{ }^{1} \mathrm{H}$ NMR $\left(400 \mathrm{MHz}, \mathrm{DMSO}-d_{6}\right): \delta 8.31$ (bs, $\left.1 \mathrm{H}\right) 8.26-8.21(\mathrm{~m}, 3 \mathrm{H}, \mathrm{Ar}-\mathrm{H}), 8.11(\mathrm{t}, J 8 \mathrm{~Hz}$, $1 \mathrm{H}, \mathrm{Ar}-\mathrm{H}), 7.92$ (bs, 1H, NH), $7.80(\mathrm{t}, J 8 \mathrm{~Hz}, 1 \mathrm{H}, \mathrm{Ar}-\mathrm{H}) 7.63(\mathrm{t}, J 8 \mathrm{~Hz}, 1 \mathrm{H}, \mathrm{Ar}-\mathrm{H}) 7.38$ (d, J $8 \mathrm{~Hz}, 1 \mathrm{H}, \mathrm{Ar}-\mathrm{H}) 2.40$ (s, $\left.3 \mathrm{H}, \mathrm{CH}_{3}\right) ;{ }^{13} \mathrm{C}$ NMR $\left(100 \mathrm{MHz}\right.$, DMSO- $\left.d_{6}\right): \delta 168.6,155.6,147.9,142.9,139.5,135.5,130.0,129.3,127.1,126.8$, 125.4, 123.1, 116.2, 20.8; HRMS (ESI) $m / z$ for $\mathrm{C}_{17} \mathrm{H}_{15} \mathrm{~N}_{2} \mathrm{O}[\mathrm{M}+\mathrm{H}]^{+}$, calcd., 263.1184, found, 263.1164

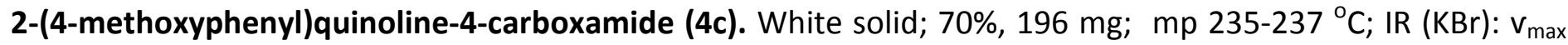
3336, 3155, 1665, $1584 \mathrm{~cm}^{-1}$; ${ }^{1} \mathrm{H}$ NMR (400 MHz, DMSO-d $)$ ): $\delta 8.30-8.22(\mathrm{~m}, 3 \mathrm{H}, \mathrm{Ar}-\mathrm{H}), 8.23(\mathrm{~d}, J 12 \mathrm{~Hz}, 1 \mathrm{H}, \mathrm{Ar}-$ H) 8.11 (bs, $1 \mathrm{H}) 8.08(\mathrm{~d}, J 8 \mathrm{~Hz}, 1 \mathrm{H}, \mathrm{Ar}-\mathrm{H}), 7.91(\mathrm{bs}, 1 \mathrm{H}, \mathrm{NH}) 7.79(\mathrm{t}, J 8 \mathrm{~Hz}, 1 \mathrm{H}, \mathrm{Ar}-\mathrm{H}), 7.60(\mathrm{t}, J 8 \mathrm{~Hz}, 1 \mathrm{H}, \mathrm{Ar}-\mathrm{H})$, $7.12(\mathrm{~d}, J 8 \mathrm{~Hz}, 2 \mathrm{H}, \mathrm{Ar}-\mathrm{H}), 3.86\left(\mathrm{~s}, 3 \mathrm{H}, \mathrm{OCH}_{3}\right) ;{ }^{13} \mathrm{C} \mathrm{NMR}\left(100 \mathrm{MHz}, \mathrm{DMSO}-d_{6}\right): \delta 168.7,160.8,155.4,147.9,142.8$, 130.7, 129.9, 129.2, 128.7, 126.5, 125.4, 122.9,116.0, 114.2, 55.3 HRMS (ESI) $\mathrm{m} / z$ for $\mathrm{C}_{17} \mathrm{H}_{15} \mathrm{~N}_{2} \mathrm{O}_{2}[\mathrm{M}+\mathrm{H}]^{+}$, calcd., 279.1133, found, 279.1144

6-chloro-2-phenylquinoline-4-carboxamide (4d). White solid; 65\%, $182 \mathrm{mg} ; \mathrm{mp} \mathrm{270-272}{ }^{\circ} \mathrm{C} ; \mathrm{IR}(\mathrm{KBr}): \mathrm{V}_{\max }$ 3372, 3153, 2980, 1647, $1584 \mathrm{~cm}^{-1} ;{ }^{1} \mathrm{H}$ NMR (400 MHz, DMSO-d $)$ : $\delta 8.41$ (bs, $\left.1 \mathrm{H}\right), 8.35(\mathrm{~d}, J 4 \mathrm{~Hz}, 1 \mathrm{H}, \mathrm{Ar}-\mathrm{H})$, $8.32(\mathrm{~d}, J 4 \mathrm{~Hz}, 2 \mathrm{H}, \mathrm{Ar}-\mathrm{H}), 8.26(\mathrm{~s}, 1 \mathrm{H} \mathrm{Ar}-\mathrm{H}), 8.15(\mathrm{~d}, J 8 \mathrm{~Hz}, 1 \mathrm{H}, \mathrm{Ar}-\mathrm{H}), 8.00(\mathrm{bs}, 1 \mathrm{H}, \mathrm{NH}), 7.84(\mathrm{dd} J 8 \mathrm{~Hz}, 4 \mathrm{~Hz}$, $1 \mathrm{H}, \mathrm{Ar}-\mathrm{H}), 7.61-7.54(\mathrm{~m}, 3 \mathrm{H}, \mathrm{Ar}-\mathrm{H}){ }^{13} \mathrm{C}$ NMR $\left(100 \mathrm{MHz}, \mathrm{DMSO}-d_{6}\right): \delta$ 168.0, 156.3, 146.5, 141.5, 137.8, 131.6, $131.5,130.6,130.1,128.9,127.3,124.2,124.0,117.8 \mathrm{HRMS}$ (ESI) $\mathrm{m} / z$ for $\mathrm{C}_{16} \mathrm{H}_{12} \mathrm{CIN}_{2} \mathrm{O}[\mathrm{M}+\mathrm{H}]^{+}, \mathrm{calcd}$., 283.0638, found, 283.0645

6-chloro-2-( $p$-tolyl)quinoline-4-carboxamide (4e). White solid; 74\%, $208 \mathrm{mg} ; \mathrm{mp} 242-244{ }^{\circ} \mathrm{C} ; \mathrm{IR}(\mathrm{KBr}): \mathrm{v}_{\max }$ 3355, 3150, 1648, $1584 \mathrm{~cm}^{-1}$; ${ }^{1} \mathrm{H}$ NMR $\left(400 \mathrm{MHz}, \mathrm{DMSO}-\mathrm{d}_{6}\right) \delta 8.40$ (bs, $\left.1 \mathrm{H}\right), 8.33$ (d, J $\left.4 \mathrm{~Hz}, 1 \mathrm{H}, \mathrm{Ar}-\mathrm{H}\right), 8.22(\mathrm{~d}, J$ $8 \mathrm{~Hz}, 2 \mathrm{H}, \mathrm{Ar}-\mathrm{H}$ ), 8.12 (d, J $12 \mathrm{~Hz}, 1 \mathrm{H}, \mathrm{Ar}-\mathrm{H}), 7.99$ (bs, $1 \mathrm{H}, \mathrm{NH}), 7.83$ (dd, J $8 \mathrm{~Hz}, 4 \mathrm{~Hz}, 1 \mathrm{H}, \mathrm{Ar}-\mathrm{H}), 7.39(\mathrm{~d}, J 8 \mathrm{~Hz}$, $2 \mathrm{H}, \mathrm{Ar}-\mathrm{H}), 2.40\left(\mathrm{~s}, 3 \mathrm{H}, \mathrm{CH}_{3}\right) ;{ }^{13} \mathrm{C} \mathrm{NMR}\left(100 \mathrm{MHz}, \mathrm{DMSO}-d_{6}\right) \delta 168.3,155.2,147.3,142.9,127.8,131.2,131.0$, 129.3, 126.4, 127.1, 124.6, 124.1, 116.4, 20.6; HRMS (ESI) $\mathrm{m} / z$ for $\mathrm{C}_{17} \mathrm{H}_{14} \mathrm{ClN}_{2} \mathrm{O}[\mathrm{M}+\mathrm{H}]^{+}$, calcd., 297.0794, found, 297.0761

6-chloro-2-(4-methoxyphenyl)quinoline-4-carboxamide (4f). White solid; 75\%, $212 \mathrm{mg}$; $\mathrm{mp} 265-267{ }^{\circ} \mathrm{C}$; IR $(\mathrm{KBr}): v_{\max } 3389,3155,2980,1650,1578 \mathrm{~cm}^{-1} ;{ }^{1} \mathrm{H}$ NMR $\left(400 \mathrm{MHz}, \mathrm{DMSO}-d_{6}\right) \delta 8.39(\mathrm{bs}, 1 \mathrm{H}), 8.32(\mathrm{~d}, J 4 \mathrm{~Hz}, 1 \mathrm{H}$, Ar-H), 8.29 (d, J $8 \mathrm{~Hz}, 1 \mathrm{H}, \mathrm{Ar}-\mathrm{H}), 8.21(\mathrm{~s}, 1 \mathrm{H}, \mathrm{Ar}-\mathrm{H}), 8.10$ (d, J $8 \mathrm{~Hz}, 1 \mathrm{H}, \mathrm{Ar}-\mathrm{H}), 7.98$ (bs, $1 \mathrm{H}, \mathrm{NH}), 7.81(\mathrm{dd}, J 8 \mathrm{~Hz}$, $4 \mathrm{~Hz}, 1 \mathrm{H}, \mathrm{Ar}-\mathrm{H}), 7.13(\mathrm{~d}, J 8 \mathrm{~Hz}, 2 \mathrm{H}, \mathrm{Ar}-\mathrm{H}), 3.86\left(\mathrm{~s}, 3 \mathrm{H}, \mathrm{OCH}_{3}\right) ;{ }^{13} \mathrm{C}$ NMR $\left(100 \mathrm{MHz}, \mathrm{DMSO}-d_{6}\right) \delta 168.1,161.0$, $156.0,146.5,141.3,131.4,131.0,130.4,130.2,128.7,124.2,123.7,117.3,114.3,55.3$; HRMS (ESI) $\mathrm{m} / z$ for $\mathrm{C}_{17} \mathrm{H}_{14} \mathrm{ClN}_{2} \mathrm{O}_{2}[\mathrm{M}+\mathrm{H}]^{+}$, calcd., 313.0743, found, 313.0736

2-(4-bromophenyl)-6-chloroquinoline-4-carboxamide (4g). White solid; 68\%, $193 \mathrm{mg}$; $\mathrm{mp} 260-262{ }^{\circ} \mathrm{C}$; IR $(\mathrm{KBr}): v_{\max } 3365,3180,2980,1655,1586 \mathrm{~cm}^{-1} ;{ }^{1} \mathrm{H}$ NMR $\left(400 \mathrm{MHz}, \mathrm{DMSO}-d_{6}\right) \delta 8.41(\mathrm{bs}, 1 \mathrm{H}), 8.35(\mathrm{~d}, J 4 \mathrm{~Hz}$, 
$1 \mathrm{H}, \mathrm{Ar}-\mathrm{H}), 8.28(\mathrm{t}, J 4 \mathrm{~Hz}, 3 \mathrm{H}, \mathrm{Ar}-\mathrm{H}), 8.15$ (d, J $8 \mathrm{~Hz}, 1 \mathrm{H}, \mathrm{Ar}-\mathrm{H}), 8.02$ (bs, 1H, NH), 7.85 (dd, J $8 \mathrm{~Hz}, 4 \mathrm{~Hz}, 1 \mathrm{H}, \mathrm{Ar}-$ $\mathrm{H}), 7.79$ (d, J $8 \mathrm{~Hz}, 2 \mathrm{H}, \mathrm{Ar}-\mathrm{H}) ;{ }^{13} \mathrm{C}$ NMR $\left(100 \mathrm{MHz}\right.$, DMSO-d $\left.d_{6}\right) \delta 172.3,167.9,155.2,146.4,141.7,136.9,131.9$, 131.6, 130.7, 129.3, 124.3, 123.9, $117.6 \mathrm{HRMS}$ (ESI) $\mathrm{m} / z$ for $\mathrm{C}_{16} \mathrm{H}_{11} \mathrm{BrClN}_{2} \mathrm{O}[\mathrm{M}+\mathrm{H}]^{+}$, calcd., 360.9743, found, 360.9755

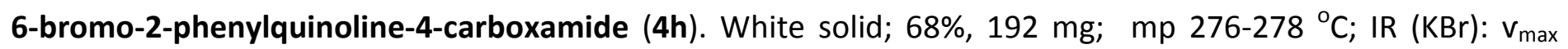
3367, 3181, 2980, 1648, $1584 \mathrm{~cm}^{-1}$; ${ }^{1} \mathrm{H}$ NMR (400 MHz, DMSO-d $)$ ): $\delta 8.51$ (d, J $\left.4 \mathrm{~Hz}, 1 \mathrm{H}, \mathrm{Ar}-\mathrm{H}\right), 8.41$ (bs, $\left.1 \mathrm{H}\right)$, $8.32(\mathrm{~d}, J 8 \mathrm{~Hz}, 2 \mathrm{H}, \mathrm{Ar}-\mathrm{H}), 8.25(\mathrm{~s}, 1 \mathrm{H}, \mathrm{Ar}-\mathrm{H}), 8.08$ (d, J $12 \mathrm{~Hz}, 1 \mathrm{H}, \mathrm{Ar}-\mathrm{H}), 8.00$ (bs, $1 \mathrm{H}, \mathrm{NH}), 7.95(\mathrm{dd}, J 8 \mathrm{~Hz}, 4 \mathrm{~Hz}$, $1 \mathrm{H}, \mathrm{Ar}-\mathrm{H}), 7.60-7.55(\mathrm{~m}, 3 \mathrm{H}, \mathrm{Ar}-\mathrm{H}) ;{ }^{13} \mathrm{C} \mathrm{NMR}\left(100 \mathrm{MHz}, \mathrm{DMSO}-d_{6}\right) \delta$ 168.0, 156.4, 146.7, 141.4, 137.8, 133.1, 131.7, 130.1, 128.9, 127.5, 127.3, 124.5, 120.2, 117.7; HRMS (ESI) $m / z$ for $\mathrm{C}_{16} \mathrm{H}_{12} \mathrm{BrN}_{2} \mathrm{O}[\mathrm{M}+\mathrm{H}]^{+}, \mathrm{calcd}$., 327.0132, found, 327.0138

6-bromo-2-(4-methoxyphenyl)quinoline-4-carboxamide (4i). White solid; 70\%, $199 \mathrm{mg} ; \mathrm{mp} 186-188{ }^{\circ} \mathrm{C}$; IR $(\mathrm{KBr}): \mathrm{V}_{\max } 3375,3180,2980,1650,1578 \mathrm{~cm}^{-1} ;{ }^{1} \mathrm{H}$ NMR $\left(400 \mathrm{MHz}, \mathrm{DMSO}-d_{6}\right) \delta 8.46(\mathrm{~s}, 1 \mathrm{H}, \mathrm{Ar}-\mathrm{H}), 8.39(\mathrm{bs}, 1 \mathrm{H})$, $8.29(\mathrm{dd}, J 8 \mathrm{~Hz}, 2 \mathrm{H}, \mathrm{Ar}-\mathrm{H}), 8.20(\mathrm{~s}, 1 \mathrm{H}, \mathrm{Ar}-\mathrm{H}), 8.02$ (d, J $8 \mathrm{~Hz}, 1 \mathrm{H}, \mathrm{Ar}-\mathrm{H}), 7.98(\mathrm{bs}, 1 \mathrm{H}, \mathrm{NH}), 7.92(\mathrm{~d}, J 8 \mathrm{~Hz}, 1 \mathrm{H}, \mathrm{Ar}-$ $\mathrm{H}), 7.12$ (d, J $12 \mathrm{~Hz}, 2 \mathrm{H}, \mathrm{Ar}-\mathrm{H}), 3.86\left(\mathrm{~s}, 3 \mathrm{H}, \mathrm{OCH}_{3}\right){ }^{13} \mathrm{C} \mathrm{NMR}\left(100 \mathrm{MHz}, \mathrm{DMSO}-d_{6}\right) \delta 168.5,156.2,146.2,142.4$, 130.1, 129.7, 128.2, 126.9, 125.8, 122.6, 116.2, 114.8, 55.6 HRMS (ESI) $m / z$ for $\mathrm{C}_{17} \mathrm{H}_{14} \mathrm{BrN}_{2} \mathrm{O}_{2}[\mathrm{M}+\mathrm{H}]^{+}, \mathrm{calcd}$., 357.0238 , found, 357.0276

\section{Acknowledgments}

R.C., S.S., and P.G. are thankful to the Department of Pharmaceuticals, Ministry of Chemical and Fertilizers, Govt. of India for providing fellowship. The authors are thankful to Dr. S. J. S. Flora, Director, NIPER, Raebareli for his support and encouragement in carrying out this research work. SAIF-CSIR-CDRI, Lucknow is greatly acknowledged for providing spectral data NIPER-R/Communication/020.

\section{References}

1. Garudachari, B.; Satyanarayana, M.N.; Thippeswamy, B.; Shivakumar, C. K.; Shivananda, K. N.; Hegde, G.; Isloor, A. M. Eur. J. Med. Chem. 2012, 54, 900.

https://doi.org/10.1016/i.ejmech.2012.05.027

2. Velu, A. B.; Chen, G. W.; Hsieh, P. T.; Horng, J. T.; Hsu, J. T.; Hsieh, H. P.; Chen, T. C.; Weng, K. F.; Shih, S. R. Antivir. Res. 2014, 112, 18.

https://doi.org/10.1016/i.antiviral.2014.10.003

3. Boa, A. N.; Canavan, S. P.; Hirst, P. R.; Ramsey, C.; Stead, A. M.; McConkey, G. A. Bioorg. Med. Chem. 2005, 13, 1945.

https://doi.org/10.1016/i.bmc.2005.01.017

4. Zarghi, A.; Ghodsi, R. Bioorg. Med. Chem. 2010, 18, 5855.

https://doi.org/10.1016/j.bmc.2010.06.094

5. Dinakaran, M.; Senthilkumar, P.; Yogeeswari, P.; China, A.; Nagaraja, V.; Sriram, D. Med. Chem. 2008, 4, 482.

https://doi.org/10.2174/157340608785700225

6. Strigacova, J.; Hudecova, D.; Varecka, L.; Lasikova, A.; Vegh, D. Folia Microbiol. 2000, 45, 305. https://doi.org/10.1007/BF02817551 
7. Wang, X.; Xie, X.; Cai, Y.; Yang, X.; Li, J.; Li, Y.; Chen, W.; He, M. Molecules 2016, 21, 340. https://doi.org/10.3390/molecules21030340

8. Sabatini, S.; Gosetto, F.; Iraci, N.; Barreca, M. L.; Massari, S.; Sancineto, L.; Manfroni, G.; Tabarrini, O.; Dimovska, M.; Kaatz, G. W.; Cecchetti, V. J. Med. Chem. 2013, 56, 4975.

https://doi.org/10.1021/jm400262a

9. Giardina, G. A. M.; Sarau, H. M.; Farina, C.; Medhurst, A. D.; Grugni, M.; Foley, J. J.; Raveglia, L. F.; Schmidt, D. B.; Rigolio, R.; Vassallo, M.; Vecchietti, V.; Hay, D. W. P. J. Med. Chem. 1996, 39, 2281. https://doi.org/10.1021/im9602423

10. Bennacef, I.; Perrio, C.; Lasne, M. C.; Barre, L. J. Org. Chem. 2007, 72, 2161. https://doi.org/10.1021/jo062285p

11. Peng, C.; Cape, J. L.; Rushmore, T.; Crouch, G. J.; Jones, J. P. J. Med. Chem. 2008, 51, 8000. https://doi.org/10.1021/im8011257

12. Dahal, U. P.; Joswig-Jones, C.; Jones, J. P. J. Med. Chem. 2012, 55,280. https://doi.org/10.1021/im201207h

13. Gopalsamy, A.; Pallai, P. V. Tetrahedron Lett. 1997, 38, 907. https://doi.org/10.1016/S0040-4039(96)02456-2

14. Aboul-Enein, H. A.; Ibrahim, S. A. J. Fluorine Chem. 1992, 59, 233. https://doi.org/10.1016/S0022-1139(00)82415-X

15. Rapport, M. M.; Senear, A. E.; Mead, J. F.; Koepfli, J. B. J. Am. Chem. Soc. 1946, 68, 2697. https://doi.org/10.1021/ja01216a085

16. Manske, R. H. Chem. Rev. 1942, 30, 113. https://doi.org/10.1021/cr60095a006

17. Beilavsky, J. Collec. Czech. Chem. Comm. 1977, 42 (9), 2802. https://doi.org/10.1135/cccc19772802

18. Mishra, P.;Agarawal, R. K.; Maini, U. K. Indian J. Pharm. Sci. 1988, 50, 269.

19. M. N. Zemtsova, A. V. Zimichev, and P. L. Trakhtenberg Izv. Vyssh. Uchebn. Zaved., Khim. Khim. Tekhnol. 2005, 48(4), 3.

20. Duvelleroy, D.; Perrio, C.; Parisel O.; Lasne, M.-C. Org. Biomol. Chem. 2005, 3794. https://doi.org/10.1039/b509400c

21. Tiwari, K. N.; Bora, D.; Chauhan, G.; Yadav, D.; Sharma, K.; Thakur, A.; Singh, L.; Tripathi, V. Synth. Commun. 2016, 46, 620. https://doi.org/10.1080/00397911.2016.1160411

22. Wang, B.; Zhu, J.; Wei, Y.; Luo, G.; Qu, H.; Liu, Liang-X. Syn. Comm. 2015, 45, 2841. https://doi.org/10.1080/00397911.2015.1111383

23. Bai, M.; You, Y.; Chen, Yong-Z., Xiang, Guang-Y.; Xu, Xiao-Y.; Zhang, Xiao-M., Yuan, Wei-C. Org. Biomol. Chem. 2016, 14, 1395. https://doi.org/10.1039/C50B02391B

24. Wadher, S. J.; Karande, N. A.; Borkar, D. S.; Yeole, P. G. Int. J. Chem. Tech. Res. 2009, 1, 1297. 